\title{
Testing of human homologues of murine obesity genes as candidate regions in Finnish obese sib pairs
}

\author{
M iina Öhman ${ }^{1}$, L aura O ksanen ${ }^{2}, \mathrm{~K}$ atariina Kainulainen ${ }^{2}$, O lli A Jänne ${ }^{3}$, Jaakko Kaprio ${ }^{4}$, \\ Markku Koskenvuo ${ }^{5}$, Pertti M ustajoki ${ }^{6}, \mathrm{~K}_{\text {immo Kontula }}^{2}$ and L eena Peltonen ${ }^{1}$ \\ ${ }^{1}$ National Public H ealth Institute, D epartment of H uman M olecular G enetics, $\mathrm{H}$ elsinki \\ ${ }^{2}$ University of $\mathrm{H}$ elsinki, D epartment of M edicine, $\mathrm{H}$ elsinki \\ ${ }^{3} \mathrm{U}$ niversity of $\mathrm{H}$ elsinki, Institute of B iomedicine, D epartment of Physiology, $\mathrm{H}$ elsinki \\ ${ }^{4} \mathrm{U}$ niversity of $\mathrm{H}$ elsinki, D epartment of Public $\mathrm{H}$ ealth and $\mathrm{N}$ ational Public $\mathrm{H}$ ealth Institute, $\mathrm{D}$ epartment of M ental \\ $\mathrm{H}$ ealth and $\mathrm{A}$ lcohol Research, $\mathrm{H}$ elsinki \\ ${ }^{5} U$ niversity of Turku, D epartment of Public H ealth, Turku \\ ${ }^{6} \mathrm{P}$ eijas H ospital, Vantaa, Finland
}

\begin{abstract}
The human homologues of recently discovered murine obesity genes provide relevant candidates to study the genetic component of obesity in humans. We analysed the human counterparts to murine obesity genes ob, db, agouti, tub, melanocortin 4-receptor (MC 4-R) and mitochondrial uncoupling proteins 2 and 3 (UCP2 and UCP3), as well as two other chromosomal regions reported to be linked to obesity-related phenotypes in restricted populations. We found no significant evidence for linkage to any analysed loci in our total study material of 105 affected sib pairs collected from the genetically homogenous population of Finland. H owever, several markers on $14 \mathrm{cM}$ chromosomal region flanking the M C 4-R gene showed sharing of alleles identical-by-descent (IBD) more frequently than expected. A selected subset of non-diabetic obese sib pairs strengthened the $P$ values down to 0.003 in this particular region. The smallest $P$ value $(P=0.001)$ was obtained with a marker $D 185487$ in a subgroup containing only sib pairs with one lean and one obese parent. We therefore screened seven obese subjects included in our sib pair material for sequence changes in their M C 4-R gene, but no mutations of apparent causal relationship were found. In conclusion, we could not find evidence for significant contribution of the chromosomal loci corresponding to the murine single gene obesity genes for human morbid obesity, but additional studies are still needed to clarify whether DNA alterations within or adjacent to the M C4-R gene play some role.
\end{abstract}

Keywords: obesity; genetics; melanocortin 4- receptor; Finnish population; sib pairs; rodent homology regions

Correspondence: Leena Peltonen, Department of Human $\mathrm{M}$ olecular $\mathrm{G}$ enetics, $\mathrm{N}$ ational Public $\mathrm{H}$ ealth Institute, $\mathrm{M}$ annerheimintie 166, FIN-00300 Helsinki, Finland. Tel: +358 9 4744 8393; Fax: +358 94744 8480; E-mail: leena.peltonen@ktl.fi

Received 3 A pril 1998; revised 20 July 1998; accepted 4 A ugust 1998 


\section{Introduction}

O besity increases the risk of cardiovascular disease, non-insulin dependent diabetes mellitus and osteoarthritis. Despite the extensive use of various preventive and treatment efforts since the 1950s, the prevalence of obesity continues to increase in all industrialised countries. ${ }^{1}$

The genetic basis of human obesity has been well demonstrated by adoption and twin studies, ${ }^{2,3}$ In fact, estimates of the heritability of body mass index (BM I) are quite high, varying from 0.5 to $0.84 .{ }^{4,5}$ Cloning of the mouse obesity genes $\mathrm{ob}, \mathrm{db}$, tub and agouti ${ }^{6-9}$ and subsequent characterisation of their mutations have been important steps in better understanding of mechanisms regulating mammalian body weight. The human homologues $O B, O B-R$ and $A S P$ of murine genes (ob, $\mathrm{db}$, agouti, respectively) have been cloned, ${ }^{10-12}$ thus providing biologically relevant candidate genes to study human obesity. The mouse region syntenic to human $11 q 13$ containing the mitochondrial uncoupling proteins $2^{13}$ and $3^{14,15}$ has been linked to obesity and noninsulin dependent diabetes using quantitative trait locus analysis in different murine models. ${ }^{16,17}$ The melanocortin-4 receptor (M C 4-R) gene has been shown to encode the target receptor for aberrant agouti protei $^{18}$ and accordingly represents an additional obesity gene candidate. One gene responsible for mouse leanness was also recently identified ${ }^{19}$ and shown to code for a regulatory subunit $(R I I \beta)$ of cA M P-dependent protein kinase. Two genome-wide searches in restricted populations, Pima Indians and $M$ exican A mericans, have reported two different loci linked to obesity-related phenotypes. A significant linkage to the percentage of body fat was found with markers on chromosome 11q21-q22 in Pima Indians, and one marker mapped on $2 q 21$ showed strong evidence of linkage with serum leptin levels in M exican A mericans. $^{20,21}$

In this study we have analysed six chromosomal regions containing human homologues of murine obesity genes and one murine 'anti-obesity' gene in a sample set of 105 obese sib pairs from the genetically isolated Finnish population. We also investigated the two other loci (11q21-q22 and 2q21) reported to be linked to obesity-related phenotypes in Pima Indians and Mexican A mericans. O ur results favour the idea that the murine homologues are not major determinants of human obesity, at least in the Finnish population. However, we found suggestive evidence for linkage between obesity and loci in the vicinity of the
M C 4-R gene, which result was strengthened in the nondiabetic subset of sib pairs as well as in the subset containing sib pairs that had one lean and one obese parent. To test the possibility that M C4-R gene mutations contribute to obesity in Finnish subjects, we sequenced the coding region, $5^{\prime}$ - and $3^{\prime}$-flanking regions in seven probands included in our study.

\section{Material and Methods}

\section{Study Subjects}

A total of 105 sib pairs concordant for obesity from 92 families were ascertained through the weight reduction programme of the Helsinki U niversity Central $\mathrm{H}$ ospital ${ }^{22}$ and the Finnish Twin Cohort. ${ }^{23}$ In the weight reduction group ( $n=252$ ), all patients were morbidly obese with a body mass index (BMI) equal to or more than $40 \mathrm{~kg} / \mathrm{m}^{2}$. Those $(n=58)$ having one or more obese siblings (BMI $\geq 32 \mathrm{~kg} / \mathrm{m}^{2}$ ) were selected for the study. A physical examination was performed to recruited sib pairs. Their medical history including the development and stability of body weight, previous and present illnesses, use of medication, consumption of alcohol and cigarettes and exercise habits was registered, and occurence of obesity in family members was recorded by interview. The parents were ascertained where possible and a detailed health questionnaire was mailed to them.

The additional 46 sib pairs from 34 families were ascertained from the dizygotic twin pairs, who replied in 1975, 1981 or 1990 to mailed questionnaires of the Finnish Twin Cohort. Each questionnaire contained items on weight and height, and those pairs in which both twins had had BM Is greater or equal to 32 were identified and invited to participate in the study. A detailed health questionnaire was sent to the selected twins, as well as sibs and parents. The participating twins were asked to give a blood sample for DNA analysis at their local health centre, where their height and weight were also recorded. Both parents were available for phase determination in $16(17 \%)$ families, one parent was available in $24(26 \%)$ families and additional sibs were ascertained in 11 families (12\%), leaving $45 \mathrm{sib}$ pairs with no additional phase information. In ten of the 92 families there were three obese siblings in a sibship and in two families there were four obese siblings. The remaining 80 families had two obese sibs in a sibship. The study protocol was approved by the Ethical Review Committee of the Department of $M$ edicine, $\mathrm{U}$ niversity of $\mathrm{H}$ elsinki. 


\section{Genotyping}

DNA was extracted according to standard procedures. $^{24}$ The subjects were genotyped using polymorphic markers within or flanking the candidate genes and loci studied. The chromosomal localisations of markers linked to human homologues are described elsewhere for $o b, d b^{11,25-27}$ and agouti. ${ }^{28}$ The human genomic region syntenic to tub locus is reported by Chung et al, ${ }^{29}$ whilst polymorphic markers near U CP2 and $U C P 3$ have been reported by several groups. ${ }^{13-15}$ $D$ etails about markers flanking M C 4-R and PRK AR 2B were found by consulting the $G$ enome $D$ ata $B$ ase (at http://gdbwww.gdb.org). In the case of intragenic markers $\mathrm{HOB}, \mathrm{OBR}-\mathrm{CTTT}$ and OBR-CA, the PCR primers were as suggested. ${ }^{30,31} \mathrm{R}$ adiation hybrid mapping ${ }^{32}$ was carried out using the Stanford $\mathrm{G} 3 \mathrm{R}$ adiation $\mathrm{H}$ ybrid Panel (R esearch Genetics, Huntsville, AL, USA) to clarify the interrelation of polymorphic markers and the MC4-R gene. The PCRs were carried out with 15-25 $\mu$ g of DNA in a reaction volume of $15-25 \mu$ using MJ R esearch thermal cycler. O ne PCR primer of each pair was labelled at its $5^{\prime}$ end by $\left(\gamma^{32} \mathrm{P}\right)$ ATP or fluorescein isothiocyanate (FITC). The ${ }^{32} \mathrm{P}$-labelled PCR products were separated by polyacrylamide gel electrophoresis in $6 \%$ denaturing gels. Autoradiography was carried out on Kodak X-O mat films. The FITC-labelled PCR products were analysed using an automated laser fluorescence (ALF) DNA-sequencing instrument (Pharmacia B iotech, Sweden). For seven of the markers, one PCR primer of each pair was labelled with fluorescent dyes FAM, HEX or TET (A pplied B iosystems, Foster City, CA , U SA ), and analysed with an automated DNA sequencer (A BI 377).

\section{Statistical Analysis}

$\mathrm{N}$ on-parametric allele-sharing method was used to determine the identical-by-descent (IBD) status of the affected sib pairs. The degree of allele-shared IBD was assessed using the SIBPA IR program..$^{33,34}$ E stimates of marker allele frequencies were obtained from the pedigree data by taking the information from parents' genotypes. In sibships of more than two siblings, this algorithm does not break them into pairs, but rather analyses them as sibships, which is generally more efficient. The statistic employed in the SIBPAIR program is computed as a lod score in which all parents are assumed to be informative for the disease, with all affected sibs inheriting the disease-predisposing allele from each parent. The 'recombination fraction' parameter in the linkage analysis is a combination of the real disease-marker recombination fraction and the per- centage of the total number of meioses which are actually informative for the disease. The use of this lod score statistic ensures that the distribution of the test statistic converges rapidly to a 50-50 mix of a $\chi^{2}$ distribution with $1 \mathrm{df}$, and a point mass at $0 .{ }^{35} \mathrm{E}$ mpirical $P$ values were computed in this study using the simulation program SIMSIBS available from ftp:/ /156.111.227.66/software/simsibs. Simulation of the sibship size distribution used in this project showed almost perfect fit to the assumed distribution, based on 1000000 replicates. Multipoint linkage analyses were performed using M A PM A KER/SIB S program. ${ }^{36}$ Linkage analyses were performed in a total material of $105 \mathrm{sib}$ pairs and also in five subsets defined by different criteria.

\section{Sequencing}

Seven obese probands included in the sib-pair analysis were selected for sequencing. The 1671 base-pair genomic sequence encompassing the coding sequence of MC4-R has been reported previously. ${ }^{37,38}$ Four separate DNA fragments covering the $5^{\prime}$ - and $3^{\prime}$-flanking regions and the entire coding region of $M C 4-R$ were amplified by PCR and sequenced using the following annealing temperatures and primers: fragment $1,57^{\circ} \mathrm{C}$, 5'-GCACAGATTCGTCTCCCAAT-3' and 5'-GCACCCTCCATCAGAGTAGC-3'; fragment 2,

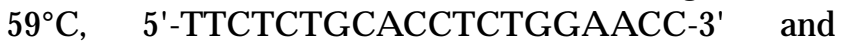
5'-CCAACCCGCTTAACTGTCAT-3'; fragment 3, $57^{\circ} \mathrm{C}, \quad 5^{\prime}-\mathrm{GTAGCTCCTTGCTTGCATCC}-3^{\prime}$ and $5^{\prime}$-T GA G A CA TGA A G CA CA CA CA A -3'; fragment 4, $55^{\circ} \mathrm{C}, \quad 5^{\prime}-\mathrm{TGAAGGGAGCGATTACCTTG-3^{ \prime }}$ and 5'-AAATCCACAGTGCCTACAACC-3'. PCR products were sequenced by cycle-sequencing using $B$ ioD ye Terminator $C y c l e$ Sequencing R eady $R$ eaction $K$ it with A mpliTaq DNA Polymerase, FS (Perkin E Imer, Foster City, CA , USA) on a model 377 automated DNA sequencer (A pplied Biosystems).

\section{Results}

In the present study, we tested for linkage between obesity and human homologues of seven murine obesity genes, one claimed 'anti-obesity' murine gene and two loci, D2S1788 and D 11S900, reported to be linked to obesity-related phenotypes in restricted populations. ${ }^{20,21}$ I nitially, 105 sib pairs were genotyped and analysed for a total of 30 polymorphic markers flanking the candidate regions. No significant evidence of linkage was detected in pairwise analyses with any of 
the markers. However, several polymorphic markers lying in the immediate vicinity of the M C4-R gene and covering a chromosomal region of $14 \mathrm{cM}$, indicated excess sharing of the alleles IBD (Figure 1). Further, the marker D 11S1321 flanking U CP 2 and U CP 3 genes showed some evidence of increased allele-sharing $(P=0.011)$ as well as the marker D 1S250 flanking the $O B-R$ gene $(P=0.054)$, but other markers in these chromosomal regions revealed no evidence for linkage. Two-point results of all the analysed markers are given in Figure 1. In our study, we could not replicate the findings of two recent genome-wide scans. ${ }^{20,21} \mathrm{O}$ ur investigation failed to demonstrate linkage of morbid obesity to either D11S900 in chromosome 11q21-q22 or D 2S1788 in chromosome 2q21. However, we tested only for linkage with the final phenotype of obesity and not with specific quantitative phenotypes, such as percentage of body fat and serum leptin levels.

In the next phase, the study sample of 105 sib pairs was divided into five different subsets in order further to increase genetic homogeneity and to dissect the clinical phenotypes. The first and second subsets were composed of sib pairs having both parents originating either from the eastern or southwestern part of Finland, respectively. This rationale was based on the well demonstrated difference in risk factors for cardiovascular diseases between eastern and southwestern Finland. ${ }^{39}$ The third group was selected to represent severe obesity having inclusion criteria B MI $\geq 37 \mathrm{~kg} / \mathrm{m}^{2}$ for all siblings in a sibship. In the fourth subgroup all diabetic individuals, defined on the basis of current medication for diabetes, were excluded. In the fifth set only sib pairs having one lean $\left(B M I \leq 26 \mathrm{~kg} / \mathrm{m}^{2}\right)$ and one obese $\left(B M I \geq 32 \mathrm{~kg} / \mathrm{m}^{2}\right.$ ) parent were accepted. The number of sib pairs in these individual subsets is given in Table 1. Two-point analyses between markers and obesity in different subsets showed further evidence for linkage for markers D 11S1321, D 1S250 and markers flanking the M C 4-R gene (D 18S851, D 18S487, D 18S69, D 18S858, D 18S849, D 18S1155, D 18S64, D 18S38). The subgroup where all diabetic subjects had been excluded proved to be the subgroup displaying the strongest association between several MC4-R gene markers and obesity (Table 1). However, the smallest $P$ value

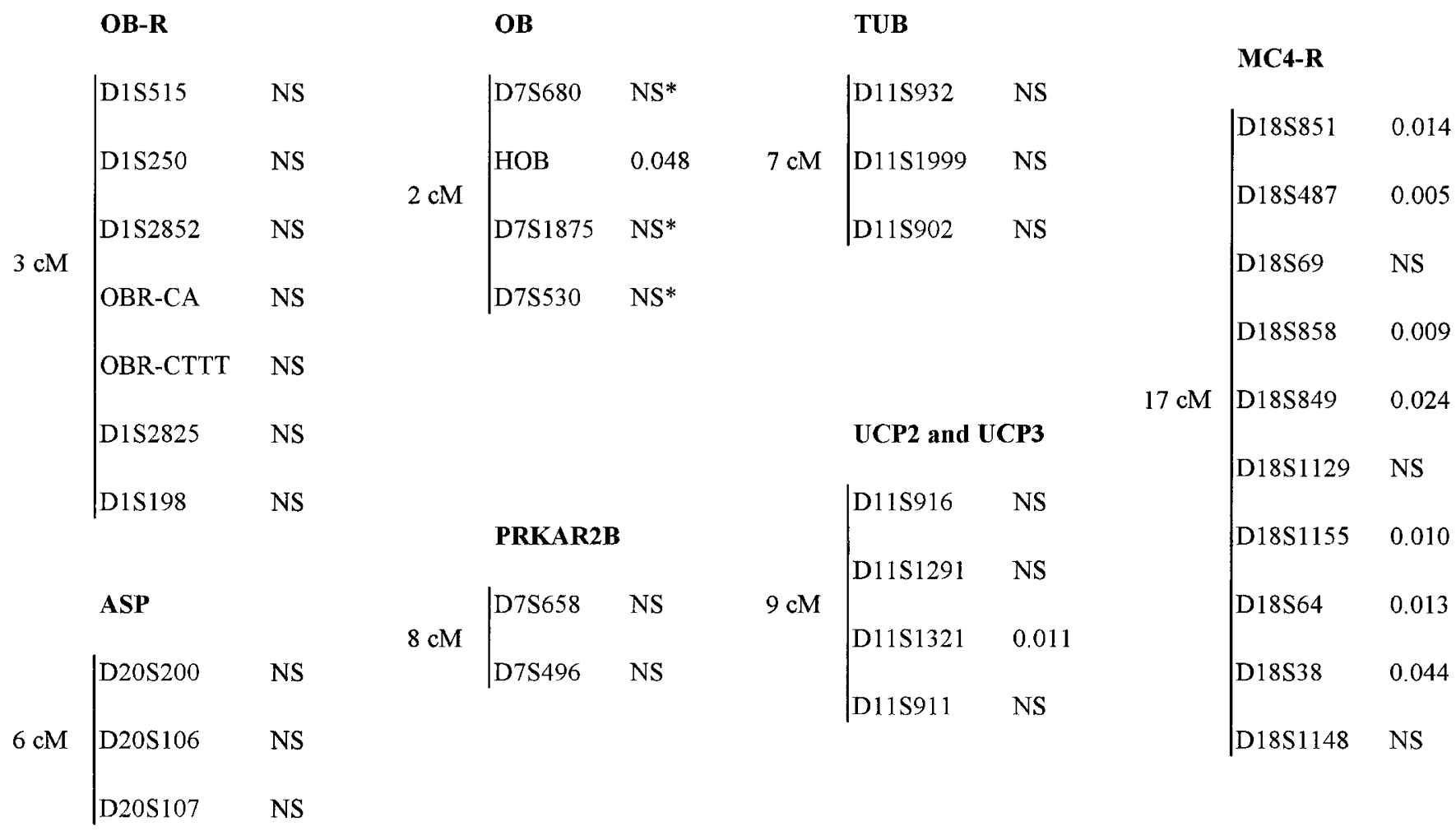

Figure 1 The P-values obtained from two-point linkage analyses between obesity and markers within and flanking the candidate genes in total material. All the P-values over 0.05 were considered nonsignificant (NS) and were excluded from further analyses. The length of different regions is indicated by centimorgans (cM) (web sites: http://www-genome.wi.mit.edu and http://cedar.genetics.soton.ac.uk/public_html/index.html). *We previously analysed several markers flanking the OB gene. 
$(P=0.001)$ was obtained with the marker D 185849 in a subgroup containing only sib pairs with one lean and one obese parent (Table 1). In order to confirm that the $P$ value 0.003 in the subsample of 80 sib pairs was still giving good fit to the theoretical distribution, a simulation was done assuming absence of linkage, in which 320 out of 100000 replicates yielded lod scores more significant than the one observed. This gave a $95 \%$ confidence interval for the $P$ value ranging on the interval $(0.0028,0.0036)$, again demonstrating the appropriateness of the assumed theoretical distribution for this analysis. A nother simulation was done to confirm the $P$ value 0.001 in the subgroup of $20 \mathrm{sib}$ pairs, and also this algorithm gave a good convergence, ie the empirical $P$ value was 0.001207 in 1000000 replicates. We also performed multipoint linkage analyses with all the markers of the M C 4-R region, but these analyses yielded no extra significance to the results obtained with the two-point analyses.

A ccordingly, we examined the coding, as well as the $5^{\prime}$ - and 3'-flanking regions of the M C4-R gene in seven unrelated probands, belonging to our sib pairs, by D NA sequencing. We found a single base substitution that replaces, as judged from the published sequence, ${ }^{38}$ valine (GTC) for isoleucine (ATC) at codon 103. Thus, all seven individuals were homozygous for the valine allele (GTC) and no isoleucine allele (ATC) was found at all. Furthermore, all individuals tested had a sequence corresponding to isoleucine (ATC) in codon 169 at which Mountjoy et al ${ }^{38}$ reported (AGC) sequence coding for serine. A Iso, one additional adenine nucleotide was found in the $3^{\prime}$-flanking region in all our obese subjects between nucleotides 1114(A) and $1115(T)$ of the published sequence. ${ }^{38} \mathrm{~A}$ ll these sequence variations found in Finnish obese subjects had previously been identified in white British males. ${ }^{40} \mathrm{No}$ other mutations or polymorphisms were identified in the analysed regions of the M C4-R gene.

\section{Discussion}

Two presuppositions were made during design of the present study. First, Finns due to their genetically isolated position and homogenous nature were considered to represent an ideal population for studies on obesity-predisposing genes. Second, combination of strategies based on the use of human homologues of novel murine obesity genes and sib-pair linkage analysis should theoretically disclose even subtle mutations or physiologically relevant genes. The Finns represent a population which has developed from a few thousand ancestors and remained isolated for several centuries. $^{41,42}$ The Finnish population offers a genetically unique tool for studies of complex diseases by its genetic homogeneity, the maintenance of excellent church records since the seventeenth century and the records of the health care system. In Finland, cultural and eating habits are similar within specific geographical regions ${ }^{39}$ and consequently differences in genetic material may explain a larger proportion of the phenotype than would be the case in a more heterogenous population. Furthermore, the use of dizygotic twins eliminates such confounding factors as age and cohort differences in dietary habits adopted at early age. The prevalence of moderate obesity in Finland is high; $18 \%$ of the adult population has BMI $\geq 30 \mathrm{~kg} /$ $\mathrm{m}^{2}{ }^{43}$ To select our study sample we applied the BMI criteria equal to or more than $32 \mathrm{~kg} / \mathrm{m}^{2}$, and phenotype information was collected by performing a physical examination and by interviewing probands as well as by mailing a detailed health questionnaire to the parents.

Table 1 The P-values obtained from two-point analyses between obesity and markers of interest (D 18S851, D 18S487, D 18S69, D 18S858, D 18S849, D 18S1129, D 18S1155, D 18S64, D 18S38) flanking the M C4-R gene and covering a region of 14cM (http://www-genome.wi.mit.edu) in total material and different subgroups

\begin{tabular}{|c|c|c|c|c|c|c|c|c|c|c|}
\hline & $\mathrm{N}$ & S851 & S487 & S69 & S858 & S849 & S1129 & S1155 & S64 & $\mathrm{S} 38$ \\
\hline Total material & 105 & 0.014 & 0.005 & 0.184 & 0.009 & 0.024 & 0.440 & 0.010 & 0.013 & 0.044 \\
\hline Parents originating from eastern Finland & 38 & 0.051 & 0.048 & 0.159 & 0.022 & 0.062 & 0.500 & 0.092 & 0.373 & 0.239 \\
\hline Parents originating from western Finland & 51 & 0.358 & 0.093 & 0.500 & 0.500 & 0.247 & 0.488 & 0.177 & 0.017 & 0.100 \\
\hline B MI $\geq 37 \mathrm{~kg} / \mathrm{m}^{2}$ for each sib, 'severe' obesity & 39 & 0.236 & 0.013 & 0.056 & 0.024 & 0.076 & 0.500 & 0.235 & 0.049 & 0.500 \\
\hline Sibs having medication for diabetes excluded & 80 & 0.004 & 0.006 & 0.061 & 0.008 & 0.003 & 0.322 & 0.014 & 0.012 & 0.017 \\
\hline $\begin{array}{l}\text { O ne parent with } \mathrm{BMI} \leq 26 \mathrm{~kg} / \mathrm{m}^{2} \text {, the other } \\
\text { with } \mathrm{BMI} \geq 32 \mathrm{~kg} / \mathrm{m}^{2}\end{array}$ & 20 & 0.074 & 0.001 & 0.072 & 0.020 & 0.006 & 0.482 & 0.129 & 0.074 & 0.093 \\
\hline
\end{tabular}

$\mathrm{N}=$ number of sib pairs in each of the subgroups. 
Since 1994, several rodent genes in which mutations cause obesity have been cloned and their counterparts in humans identified (for review see Chagnon and B ouchard ${ }^{44}$ ). A whole new biological signalling route from adipose tissue to the brain was discovered ${ }^{45}$ following the cloning of the mouse ob gene ${ }^{7}$ and ever since the new hormone, leptin, has been under extensive studies. ${ }^{46-48} \mathrm{U}$ sing human homologues of rodent genes as candidates to study human diseases has been successfully applied in the study of another complex disease, multiple sclerosis. ${ }^{33}$

Here we report that the sib pairs shared alleles identical-by-descent more often than expected by chance for the markers flanking the MC4-R gene in subgroups of sib pairs derived from the original material of 105 obese pairs. In our initial two-point linkage analysis of the total study set, we could not find any marker with significant evidence for linkage. H owever, the $14 \mathrm{CM}$ region containing the M C 4-R gene showed strengthened $P$ values when subjects receiving medication for diabetes were excluded (Table 1 ). A lthough the $P$ values did not reach a level of indubitable significance, the wideness of the positive region around the MC4-R gene may reflect a true linkage. R ecently, Terwilliger et al ${ }^{49}$ showed by analytical argument and simulation experiments that true peaks are, on average, longer than false peaks and that longer peaks are more likely to contain the gene of interest than are shorter peaks. Thus, compared with candidate genes $O B-R, U C P 2$ and U CP 3 with only one positive marker in the respective regions, the MC4-R region containing several positive markers could represent a reliable linkage (Figure 1). These data prompted us to examine by DNA sequencing the entire coding region of M C4-R in seven probands included in our sibpair analysis. In addition, 5'- and $3^{\prime}$-flanking regions were examined in selected individuals. We found a nucleotide substitution that replaces valine (GTC) for isoleucine (ATC) at codon 103 of the published M C 4-R sequence. ${ }^{38} \mathrm{~A}$ II Finnish subjects were homozygous for the valine allele. Compared with the published sequence ${ }^{38}$ we found, similar to Gotoda et al, ${ }^{40}$ two other sequence differences. Since the alterations comprising these three sites do not alter the coding region of the MC4-R gene, they are unlikely to explain the obese phenotype in Finnish subjects.

In previous studies, weak evidence of linkage between markers flanking the $O B$ gene and morbid obesity was initially reported, ${ }^{25,50}$ but contrasting data have been presented. ${ }^{22,51}$ In a population-based study of Pima Indians, no significant linkage to any rodent obesity gene was found, ${ }^{51}$ although an association between a variation at the $O B-R$ gene and obesity in the same population was reported. ${ }^{52} \mathrm{~F}$ urther, tentative linkages of various obesity- and diabetes-related quantitative phenotypes to the region containing the OB-R gene were detected in a study of sibships derived from the Q uebec Family Study, ${ }^{53}$ whereas no association was found between mutations of the $O B-R$ gene and human obesity in the B ritish male population.$^{54}$ These conflicting data most probably indicate problems in the definition of modelling of the inheritance and dissection of the clinical phenotype or modification of gene effects by varying environments. Recently, no association was found between a missense variant of melanocortin-4 receptor and obesity, plasma glucose or insulin in white British males. ${ }^{40} \mathrm{~A}$ linkage was observed between MC5-R and BMI as well as an association between M C 4-R and fat mass in sib pairs of the Q uebec Family Study. ${ }^{55} \mathrm{~A}$ strong linkage between markers in the vicinity of the U CP2 and resting metabolic rate was also detected in French Canadian pedigrees. ${ }^{56}$ Recent studies ${ }^{57-59}$ have shown that mutations in leptin and leptin receptor genes exist in humans and cause morbid obesity and pituitary dysfunction. Furthermore, functional leptin and leptin receptor are required for the initiation of puberty and establishment of secondary sexual characteristics in humans. A nother rare gene mutation affecting prohormone convertase 1 (PC1) was recently identified in an obese subject. ${ }^{60}$ The proband had similar phenotype to that of the fat/fat mouse, ${ }^{61,62}$ suggesting that molecular defects in prohormone conversion may represent a generic mechanism for obesity. A fourth gene responsible for human obesity has been reported ${ }^{63}$ recently: pre-pro-opiomelanocortin (POMC) mutations cause adrenal insufficiency and red hair pigmentation in addition to severe early onset of obesity.

In conclusion, in our candidate gene approach based on the systematic screening of human homologues of murine obesity genes, we could not identify a major gene predisposing to obesity in Finnish sibships, but observed excess sharing of alleles IBD on a wide chromosomal region containing the MC4-R gene. We sequenced the entire coding region, $5^{\prime}$ - and $3^{\prime}$-flanking regions of $M C 4-R$ in seven obese subjects included in our sib-pair study, but could not identify any defect that could alter the coding region and thus the function of the protein. It is unlikely that structural alterations of the MC4-R protein would be a major mechanism 
explaining human obesity, at least in the Finnish population, but additional genetic studies on the chromosome $18 q 21.3$ region may be warranted.

\section{Acknowledgements}

We are greatly indebted to Dr M arkus Perola for valuable advice, endless help and support. We thank Dr Joseph Terwilliger for statistical advice. $\mathrm{Mr}$ Tero Juntunen and $\mathrm{Mr}$ Teemu Perheentupa are thanked for their helpfulness during the preparation of the manuscript. M s Pirkko Särkijärvi and M s E ila Voipio did most of the work required in contacting the twins and their families, which is gratefully acknowledged. We are thankful to M s M erja Lindfors for expert technical assistance. We wish to thank all the patients and their families for participation. This study was supported by research grants from The Finnish $\mathrm{H}$ eart Foundation, The $\mathrm{H}$ jelt Foundation, The A cademy of Finland, The Sigrid J uselius Foundation and The E mil A altonen Foundation.

\section{References}

1 Rosenbaum M, Leibel RL, H irsch J: O besity. N Engl J $M$ ed 1997; 337: 396-407.

2 Stunkard A J, H arris J R, Pedersen N L, M cClearn GE : The body-mass index of twins who have been reared apart. $\mathrm{N}$ Engl J M ed 1990; 322: 1483-1487.

3 Bouchard C, Despres J-P, M auriege P: Genetic and nongenetic determinants of regional fat distribution. Endocr Rev 1993; 14: 72-93.

4 Stunkard A J, Foch TT, H rubec Z: A twin study of human obesity. J A m Med A ssoc 1986; 256: 51-54.

5 A llison D B, Kaprio J, Korkeila M, Koskenvuo M, Neale MC, H ayakawa K: The heritability of body mass index among an international sample of monozygotic twins reared apart. Int J O besity 1996; 20: 501-506.

6 Bultman SJ, M ichaud EJ, Woychik R P: M olecular characterization of the mouse agouti locus. Cell 1992; 71: 1195- 1204.

7 Zhang $Y$, Proenca $R$, M affei $M$, Barone $M$, L eopold L, Friedman J M : Positional cloning of the mouse obese gene and its human homologue. $N$ ature 1994; 372: 425-432.

8 Tartaglia LA , D embski M , Weng X et al: I dentification and expression cloning of a leptin receptor, O B-R . Cell 1995; 83: 1263-1271.

9 Kleyn PW, Fan W, Kovats SG et al: Identification and characterization of the mouse obesity gene tubby: A member of a novel gene family. Cell 1996; 85: 281-290.

$10 \mathrm{~K}$ won HY, Bultman S], L öffler C et al: M olecular structure and chromosomal mapping of the human homolog of the agouti gene. Proc Natl Acad Sci USA 1994; 91: 9760-9764.

11 G reen ED, M affei $M, B$ raden $V V$ et al: The human obese (OB) gene: RNA expression pattern and mapping on the physical, cytogenetic, and genetic maps of chromosome 7 . G enome Res 1995; 5: 5-12.
12 Chung WK, Power-K ehoe L, Chua $M$, L ee R, L eibel R L: $G$ enomic structure of the human $O B$ receptor and identification of two novel intronic microsatellites. $G$ enome Res 1996; 6: 1192-1199.

13 Fleury C, Neverova $M$, Collins $S$ et al: Uncoupling protein-2: a novel gene linked to obesity and hyperinsulinemia. N at G enet 1997; 15: 269-272.

14 Gong DW, He Y, Karas M, Reitman M: Uncoupling protein-3 is a mediator of thermogenesis regulated by thyroid hormone, beta3-adrenergic agonists, and leptin. J Biol Chem 1997; 272: 24129-24132.

15 Solanes G, Vidal-Puig A, Grujic D, Flier J S, L owell B B: The human uncoupling protein-3 gene. Genomic structure, chromosomal localization, and genetic basis for short and long form transcripts. J Biol Chem 1997; 272: 25433-25436.

16 Warden $\mathrm{CH}$, Fisler J S, Shoemaker SM et al: I dentification of four chromosomal loci determining obesity in a multifactorial mouse model. J Clin Invest 1995; 95: 1545-1552.

17 Taylor BA, Phillips S]: Detection of obesity QTLs on mouse chromosomes 1 and 7 by selective DNA pooling. Genomics 1996; 34: 389-398.

18 H uszar D, Lynch CA , Fairchild-H untress $V$ et al: Targeted disruption of the melanocortin-4 receptor results in obesity in mice. Cell 1997; 88: 131-141.

19 Cummings DE, Brandon EP, Planas JV, M otamed $K$, Idzerda RL, M cK night GS: G enetically lean mice result from targeted disruption of the RII beta subunit of protein kinase A. Nature 1996; 382: 622-626.

20 Norman RA, Thompson DB, Foroud T et al: Genomewide search for genes influencing percent body fat in Pima Indians: suggestive linkage at chromosome 11q21-q22. Pima Diabetes G ene Group. A m J H um G enet 1997; 60: 166- 173.

21 Comuzzie AG, Hixson JE, A Imasy $L$ et al: A major quantitative trait locus determining serum leptin levels and fat mass is located on human chromosome 2 . N at Genet 1997; 15: 273-276.

22 O ksanen L, O hman M, H eiman M et al: Markers for the gene $o b$ and serum leptin levels in human morbid obesity. H um G enet 1997; 99: 559-564.

23 Korkeila M, Kaprio J, R issanen A, Koskenvuo M : E ffects of gender and age on the heritability of body mass index. Int J O besity 1991; 15: 647-654.

24 Sambrook J, Fritsch EF, M aniatis T: Molecular Cloning Cold Spring $\mathrm{H}$ arbor Laboratory Press, N ew York, 1989.

25 R eed DR, D ing Y, X u W, Cather $C, G$ reen E D, Price R A : Extreme obesity may be linked to markers flanking the human O B gene. Diabetes 1996; 45: 691-694.

26 M cG uire RE , Jordan SA, Braden V V et al: M apping the R P10 locus for autosomal dominant retinitis pigmentosa on 7q: refined genetic positioning and localization within a well-defined YAC contig. G enome Res 1996; 6: 255-266.

27 Winick JD, Stoffel M, Friedman J M: Identification of microsatellite markers linked to the human leptin receptor gene on chromosome 1. G enomics 1996; 36: 221-222.

28 Wilson BD, Ollmann MM, Kang L, Stoffel M, B ell GI, Barsh GS: Structure and function of A SP, the human homolog of the mouse agouti gene. $\mathrm{H}$ um M ol G enet 1995: 4: $223-230$. 
29 Chung W, Goldberg-Berman J, Power-Kehoe L, Leibel $\mathrm{RL}$ : Molecular mapping of the tubby (tub) mutation on mouse chromosome 7. G enomics 1996; 32: 210-217.

30 Chung WK, Power-K ehoe L, Chua M, L eibel RL: Mapping of the $O B$ receptor to $1 p$ in a region of nonconserved gene order from mouse and rat to human. Genome Res 1996; 6: 431-438.

31 Shintani $M$, Ikegami $H$, Yamato $E$ et al: A novel microsatellite polymorphism in the human $O B$ gene: $a$ highly polymorphic marker for linkage analysis. Diabetologia 1996; 39: 1398-1401.

32 Cox DR, Burmeister M, Price ER, K im S, Myers R M : $R$ adiation hybrid mapping: a somatic cell genetic method for constructing high-resolution maps of mammalian chromosomes. Science 1990; 250: 245-250.

33 Kuokkanen S, Sundvall M, Terwilliger J D et al: A putative vulnerability locus to multiple sclerosis maps to 5p14-p12 in a region syntenic to the murine locus $\mathrm{E}$ ae2. $\mathrm{N}$ at $\mathrm{G}$ enet 1996; 13: 477-480.

34 Satsangi J, Parkes M, L ouis E et al: Two stage genomewide search in inflammatory bowel disease provides evidence for susceptibility loci on chromosomes 3, 7 and 12. N at G enet 1996; 14: 199-202.

35 Nordheim E V, Tsiatis A, Shapas TJ : Incorporating extra information in experimental design for bioassay. Biometrics 1983; 39: 87-96.

36 Kruglyak L, Lander ES: Complete multipoint sib-pair analysis of qualitative and quantitative traits. A m J H um G enet 1995; 57: 439-454.

37 Gantz I, Miwa H, Konda $Y$ et al: Molecular cloning, expression, and gene localization of a fourth melanocortin receptor. J Biol Chem 1993; 268: 15174-15179.

38 Mountjoy K G, Mortrud M T, Low MJ, Simerly R B, Cone $R D$ : L ocalization of the melanocortin-4 receptor (MC4-R) in neuroendocrine and autonomic control circuits in the brain. M ol Endocrin 1994; 8: 1298-1308.

39 Vartiainen E, Puska P, Jousilahti $\mathrm{P}$, Korhonen HJ, Tuomilehto J, Nissinen A : Twenty-year trends in coronary risk factors in north $\mathrm{K}$ arelia and in other areas of Finland. Int J E pid 1994; 23: 495-504.

40 G otoda T, Scott J, A itman T] : M olecular screening of the human melanocortin-4 receptor gene: identification of a missense variant showing no association with obesity, plasma glucose, or insulin. Diabetologia 1997; 40: 976-979.

41 Norio R, Nevanlinna HR, Perheentupa J: Hereditary diseases in Finland; rare flora in rare soul. A nn Clin Res 1973; 5: 109-141.

42 Nevanlinna HR: The Finnish population structure. A genetic and genealogical study. Hereditas 1972; 71: 195-236.

43 Pietinen $P$, Vartiainen $E, M$ annisto S: Trends in body mass index and obesity among adults in Finland from 1972 to 1992. Int J O besity 1996; 20: 114- 120.

44 Chagnon Y C, B ouchard C: G enetics of obesity: advances from rodent studies. TIG 1996; 12: 441-444.

45 Campfield LA, Smith FJ, Guisez Y, D evos R, Burn P: $R$ ecombinant mouse $O B$ protein: evidence for a peripheral signal linking adiposity and central neural networks. Science 1995; 269: 546-549.

46 Kolaczynski J W, Nyce M R, Considine RV et al: A cute and chronic effects of insulin on leptin production in humans: Studies in vivo and in vitro. Diabetes 1996; 45: 699-701.
47 M urakami $T$, Iida $M$, Shima $K$ : D examethasone regulates obese expression in isolated rat adipocytes. Biochem Biophys Res Commun 1995; 214: 1260-1267.

48 R osenbaum M, Nicolson M, Hirsch J et al: Effects of gender, body composition, and menopause on plasma concentrations of leptin. J Clin Endocrinol Metab 1996; 81: 3424-3427.

49 Terwilliger J D, Shannon WD, L athrop GM et al: True and false positive peaks in genomewide scans: applications of length-biased sampling to linkage mapping. Am J H um G enet 1997; 61: 430-438.

50 Clement K, G arner C, H ager J et al: Indication for linkage of the human $O B$ gene region with extreme obesity. D iabetes 1996; 45: 687-690.

51 Norman RA, Leibel RL, Chung WK et al: A bsence of linkage of obesity and energy metabolism to markers flanking homologues of rodent obesity genes in Pima Indians. D iabetes 1996; 45: 1229-1232.

52 Thompson DB, Ravussin E, B ennett PH, Bogardus $C$ : Structure and sequence variation at the human leptin receptor gene in lean and obese Pima Indians. $\mathrm{H}$ um $\mathrm{M} \mathrm{ol}$ G enet 1997; 6: 675-679.

53 Chagnon Y C, Perusse L, Lamothe $M$ et al: Suggestive linkages between markers on human 1p32-p22 and body fat and insulin levels in the Quebec Family Study. O bes Res 1997; 5: 115-121.

54 Gotoda T, Manning BS, Goldstone A P et al: Leptin receptor gene variation and obesity: lack of association in a British male population. Hum Mol Genet 1997; 6: 869-876.

55 Chagnon $Y C$, Chen $W J$, Perusse $L$ et al: Linkage and association studies between the melanocortin receptors 4 and 5 genes and obesity-related phenotypes in the Q uebec Family Study. M ol M ed 1997; 3: 663-673.

56 Bouchard C, Perusse L, Chagnon Y C, Warden C, R icquier $D$ : Linkage between markers in the vicinity of the uncoupling protein 2 gene and resting metabolic rate in humans. H um Mol G enet 1997; 6: 1887-1889.

57 Clement $\mathrm{K}$, Vaisse $\mathrm{C}$, Lahlou $\mathrm{N}$ et al: A mutation in the human leptin receptor gene causes obesity and pituitary dysfunction. Nature 1998; 392: 398-401.

58 Strobel A, I ssad T, Camoin L, O zata M, Strosberg A D : A leptin missense mutation associated with hypogonadism and morbid obesity. Nat G enet 1998; 18: 213-215.

59 M ontague CT, Farooqi IS, W hitehead J P et al: Congenital leptin deficiency is associated with severe early-onset obesity in humans. Nature 1997; 387: 903-908.

60 Jackson R S, Creemers JWM , O hagi S et al: Obesity and impaired prohormone processing associated with mutations in the human prohormone convertase 1 gene. $\mathrm{N}$ at Genet 1997; 16: 303-306.

61 Naggert JK, Fricker LD, Varlamov 0 et al: Hyperproinsulinaemia in obese fat/fat mice associated with a carboxypeptidase $\mathrm{E}$ mutation which reduces enzyme activity. N at G enet 1995; 10: 135-142.

62 Cool D R, N ormant E, Shen F et al: Carboxypeptidase E is a regulated secretory pathway sorting receptor: genetic obliteration leads to endocrine disorders in Cpe(fat) mice. Cell 1997; 88: 73-83.

63 Krude H, Biebermann H, Luck W, Horn R, Brabant G Gruters A: Severe early-onset obesity, adrenal insufficiency and red hair pigmentation caused by pomc mutations in humans. Nat G enet 1998; 19: 155-157. 